\title{
Synthesis and Characterization of $\operatorname{Ir}(\mathrm{H})(\mathrm{CO})\left(\mathrm{PEt}_{3}\right)_{2}\left(\eta^{2}-\mathrm{C}_{60}\right)^{\dagger}$
}

\author{
Chang Yeon Lee, Gaehang Lee. Hongkyu Kang, Bo Keun Park, and Joon T. Park ${ }^{*}$
}

\author{
Deparment of Chemistry and School of Molecular Science (BK21), Korea Advanced Institute of Science and Technology, \\ Daejeon 305-701, Korea. "E-mail:joontpark@kaist.ac.kr
}

Received Jtine 28, 2007

\begin{abstract}
The title complex, $\operatorname{Ir}(\mathrm{H})(\mathrm{CO})\left(\mathrm{PEt}_{3}\right),\left(\eta^{2}-\mathrm{C}_{60}\right)(2)$, has been prepared by the reaction of excess $\mathrm{C}_{60}$ (4 equiv) with a tetrairidium complex $\operatorname{Ir}_{4}\left(\mathrm{CO}_{2}\left(\mathrm{PEt}_{3}\right)_{4}\right.$ (1) in refluxing chlorobenzene in $40 \%$ yield as green crystals. Compound 2 has been characterized by cyclic voltammetry (CV), spectroscopic methods (mass, $I R,{ }^{1} \mathrm{H}$ and ${ }^{31} \mathrm{P}$ $\mathrm{NMR}$ ), and a single crystal X-ray diffraction study. The molecular structure reveals that the iridium atom of $\mathbf{2}$ is coordinated by two axial ligands of a hydrogen atom and a carbonyl group, and three equatorial ligands of two phosphorus atoms and an $\eta^{2}$ - $\mathrm{C}_{60}$ moiety. The $\mathrm{CV}$ study exhibits three reversible one-electron redox waves for the successive reductions of $\mathbf{2}$, together with additional four redox waves due to free $\mathrm{C}_{6 \phi}$ reductions, which was formed by decomposition of $\mathbf{2}$ in the reduced states. The three reversible redox waves of $\mathbf{2}$ are shifted to more negative potentials by $c a .270 \mathrm{mV}$ compared to free $\mathrm{C}_{60}$, reflecting both metal-to- $\mathrm{C}_{60} \pi$-back-donation and the electron-donating nature of the two phosphorus ligands.
\end{abstract}

Key Words : Metallofullerene, Iridium, Crystal structure, Cyclic voltammetry

\section{Introduction}

Since the first $\mathrm{C}_{60}$ transition metal complex with a direct metal- $\mathrm{C}_{(i)}$ bond, $\mathrm{Pt}\left(\mathrm{PPh}_{3}\right)_{2}\left(\eta^{2}-\mathrm{C}_{(v)}\right)^{\prime}$, has been reported, intensive studies in the field of exohedral metallofullerenes have been carried out to understand the effect of metal coordination on the chemical and physical properties of $\mathrm{C}_{(0)}{ }^{2}{ }^{2}$ Numerous $\eta^{2}-\mathrm{C}_{60}$ monometallic transition metal complexes have been reported for $\mathrm{Ta}, \mathrm{Mo}, \mathrm{W}, \mathrm{Fe}, \mathrm{Ru}, \mathrm{Co}, \mathrm{Rh}$, Ir, Ni, Pd, and $\mathrm{Pt}$ metals. ${ }^{2-5}$ Subsequent development in $\mathrm{C}_{60}$-metal $\pi$ complex chemistry has led to the syntheses of $\mu-\eta^{2}: \eta^{2}-\mathrm{C}_{60}$ complexes for $\mathrm{Re}, \mathrm{Ru}$, and Ir metals ${ }^{6}$ and $\mu_{3}-\eta^{2}: \eta^{2}: \eta^{2}-\mathrm{C}_{60}$ complexes for Re, $\mathrm{Ru}, \mathrm{Os}, \mathrm{Rh}$, and Ir metals. ${ }^{\text {? }}$

The hydrido iridium compound, $\operatorname{Ir}(\mathrm{H})(\mathrm{CO})\left(\mathrm{PPh}_{3}\right)_{3}$, is a well-known catalyst for both hydrogenation and isomerization catalysts of alkenes and alkynes. ${ }^{8}$ Its fullerenesubstituted compound, $\operatorname{Ir}(\mathrm{H})(\mathrm{CO})\left(\mathrm{PPh}_{3}\right)_{2}\left(\eta^{2}-\mathrm{C}_{60}\right)(3),{ }^{9}$ has been previously reported from the reaction of $\mathrm{C}_{(\alpha)}$ with octahedral $\operatorname{Ir}(\mathrm{H})_{2}(\mathrm{Cl})(\mathrm{CO})\left(\mathrm{PPh}_{3}\right)_{2}$ by elimination of $\mathrm{HCl}$, but has not been structurally characterized, although a chloro analogue of 3 was prepared from the reaction of $\mathrm{C}_{60}$ with $\operatorname{Ir}(\mathrm{Cl})(\mathrm{CO})\left(\mathrm{PPh}_{3}\right)_{2}$ and its crystal structure was reported. ${ }^{10}$ Herein we report full details of synthetic, structural, spectroscopic, and electrochemical characterization of $\operatorname{Ir}(\mathrm{H})(\mathrm{CO})$ $\left(\mathrm{PEt}_{3}\right)_{2}\left(\eta^{2}-\mathrm{C}_{60}\right)(2)$, a triethylphosphine analogue of 3 , isolated serendipitously from the reaction of the tetrakistriethylphosphine-substituted compound $\mathrm{Ir}_{4}(\mathrm{CO})_{8}\left(\mathrm{PEt}_{3}\right)_{4}$ (1) with $\mathrm{C}_{\text {(1) }}$.

\section{Experimental Section}

General Techniques. All reactions were carried out under a nitrogen atmosphere with use of standard Schlenk

${ }^{\dagger}$ This paper is dedicated to Professor Sang Chul Shim on the occasion of his honorable retirement. techniques. Solvents were dried over the appropriate drying agents and distilled immediately before use. $\mathrm{C}_{60}(99.5 \%$, SES Research) and $\mathrm{PEt}_{3}(1.0 \mathrm{M} \mathrm{THF}$ solution, Aldrich) were used without further purification, and $\operatorname{Ir}_{4}(\mathrm{CO})_{8}\left(\mathrm{PEt}_{3}\right)_{4}(\mathbf{1})$ was prepared according to the literature procedure. ${ }^{11}$ Preparative thin layer plates $(\mathrm{tlc})$ were prepared with silica gel $\mathrm{GF}_{2: 4}$ (Type 60, E. Merck). Infrared spectra were obtained on a Bruker EQUINOX-55 FT-IR spectrophotometer. ${ }^{1} \mathrm{H}$ NMR $(400 \mathrm{MHz})$ spectra were recorded on a Bruker AVANCE-400 spectrometer and ${ }^{31} \mathrm{P}\left\{{ }^{1} \mathrm{H}\right\}$ NMR (122 MHz) spectrum were recorded on a Bruker AM-300 spectrometer. Positive ion $\mathrm{FAB}$ mass spectra $\left(\mathrm{FAB}^{+}\right)$were obtained by the staff of the Korea Basic Science Institute and all $\mathrm{m} / \mathrm{z}$ values were referenced to ${ }^{193}$ Ir. Elemental analyses were provided by the staff of the Energy and Environment Research Center at KAIST.

Preparation of $\operatorname{Ir}(\mathrm{H})(\mathrm{CO})\left(\mathrm{PEt}_{3}\right)_{2}\left(\eta^{2}-\mathrm{C}_{60}\right)$ (2). A chlorobenzene solution $(30 \mathrm{~mL})$ of $\operatorname{Ir}_{4}(\mathrm{CO})_{8}\left(\mathrm{PEt}_{3}\right)_{4}(1,30 \mathrm{mg}$, $0.020 \mathrm{mmol})$ and an excess of $\mathrm{C}_{\mathrm{CD}}(58 \mathrm{mg}, 0.080 \mathrm{mmol}, 4$ equiv) was heated to reflux for $10 \mathrm{~h}$ with stirring and the color changed to a green solution. The solvent was evaporated and the residue was purified by preparative tlc with a $\mathrm{CS}_{2}$ eluent. Recrystallization in $\mathrm{CS}_{2}$ with $\mathrm{EtOH}$ as a layering solvent afforded compound $2\left(9 \mathrm{mg}, 0.008 \mathrm{mmol}, 40 \%, R_{f}=\right.$ $0.56)$ as black crystals. IR $\left(\mathrm{CH}_{2} \mathrm{Cl}_{2}\right) v_{\mathrm{r}-\mathrm{H}} 209 \mathrm{l}(\mathrm{m}), v_{\mathrm{CO}} 2091$ (m); ${ }^{1} \mathrm{H} \mathrm{NMR}\left(\mathrm{CDCl}_{3}, 298 \mathrm{~K}\right) \delta 2.23\left(\mathrm{~m}, 12 \mathrm{H}, \mathrm{P}\left(\mathrm{CH}_{2} \mathrm{CH}_{3}\right)_{3}\right)$, $1.34\left(\mathrm{dt}, J_{\mathrm{HII}}=7.8 \mathrm{~Hz} ;{ }^{3} \mathrm{~J}_{\mathrm{PII}}=15.9 \mathrm{~Hz}, 18 \mathrm{H}, \mathrm{P}\left(\mathrm{CH}_{2} \mathrm{CH}_{3}\right)_{3}\right)$, $-9.70\left(\mathrm{t},{ }^{2} J_{\mathrm{PII}}=18.8 \mathrm{~Hz}, 1 \mathrm{H}, \mathrm{Ir}-H\right) ;{ }^{13} \mathrm{C}\left\{{ }^{1} \mathrm{H}\right\} \mathrm{NMR}\left(\mathrm{CS}_{2} /\right.$ THF-d $4,298 \mathrm{~K}$, CO region) $\delta 179.1$ (br, $\left.1 \mathrm{CO}),{ }^{13} \mathrm{C}_{\{}{ }^{1} \mathrm{H}\right\}$ NMR $\left(\mathrm{CS}_{2} / \mathrm{THF}-\mathrm{d}_{4}, 298 \mathrm{~K}, \mathrm{C}_{60}\right.$ region) $\delta 167.1(2 \mathrm{C})$, $165.4(2 \mathrm{C}), 148.3(2 \mathrm{C}), 148.0(2 \mathrm{C}), 147.0(1 \mathrm{C}), 146.8(1 \mathrm{C})$, $145.8(2 \mathrm{C}), 145.7(2 \mathrm{C}), 145.3(2 \mathrm{C}), 145.0(2 \mathrm{C}), 144.9(2 \mathrm{C})$, $144.8(6 \mathrm{C}), 144.3(1 \mathrm{C}), 144.2(1 \mathrm{C}), 143.8(2 \mathrm{C}), 143.7(2 \mathrm{C})$, $143.6(2 \mathrm{C}), 143.5(2 \mathrm{C}), 143.3(2 \mathrm{C}), 142.7(2 \mathrm{C}), 142.6(2 \mathrm{C})$, $142.4(2 \mathrm{C}), 142.3(2 \mathrm{C}), 142.0(2 \mathrm{C}), 141.9(2 \mathrm{C}), 141.6(2 \mathrm{C})$, 
$141.5(2 \mathrm{C}), 134.7(2 \mathrm{C}), 134.3(2 \mathrm{C}), 60.3\left(\mathrm{t}, J_{\mathrm{PC}}=12.5 \mathrm{~Hz}, 2 \mathrm{C}\right.$, $\mathrm{sp}^{3}$ carbon). ${ }^{31} \mathrm{P}\left\{{ }^{1} \mathrm{H}\right\}$ NMR $\left(\mathrm{CDCl}_{3}, 298 \mathrm{~K}\right) \delta-6.9(\mathrm{~s}, 2 \mathrm{P}$, $\left.\mathrm{PEt}_{3}\right)$. MS $\left(\mathrm{FAB}^{+}\right): \mathrm{m} / \mathrm{z}: 1178\left[M^{+}\right]$. Anal. Calc. for $\mathrm{C}_{73} \mathrm{H}_{31} \mathrm{P}_{2} \mathrm{OIr} \cdot 0.5 \mathrm{CS}_{2}: \mathrm{C}, 72.6 ; \mathrm{H} 2.57$, Found:C, 73.2; $\mathrm{H}$, 2.58 .

Electrochemical Measurements. Cyclic voltammetry was carried out on a AUTOLAB (PGSTAT 10, Eco Chemie, Netherlands) electrochemical analyzer using the conventional three electrode system of a platinum working electrode (1.6 mm diameter disk, Bioanalytical Systems, Inc.), a platinum counter wire electrode $(5 \mathrm{~cm}$ length of $0.5 \mathrm{~mm}$ diameter wire), and a $\mathrm{Ag} / \mathrm{Ag}^{+}$reference electrode $(0.1 \mathrm{M}$ $\mathrm{AgNO}_{3} / \mathrm{Ag}$ in acetonitrile with a $\mathrm{Vycor}{ }^{\mathrm{TM}}$ salt bridge). All the measurements were performed at ambient temperature under nitrogen atmosphere in a dry deoxygenated $0.1 \mathrm{M}$ chlorobenzene solution of $\left[(n-\mathrm{Bu})_{4} \mathrm{~N}\right] \mathrm{ClO}_{4}$. The concentrations of compounds were ca. $3 \times 10^{-4} \mathrm{M}$. All potentials were referenced to the standard ferrocene/ferrocenium $(\mathrm{Fc} /$ $\mathrm{Fc}^{+}$) scale. Relative number of electrons involved in each reduction process was obtained from the graph of current vs. (time) $)^{-1 / 2}$ according to the Cottrell equation.

\section{$X$-ray Data Collection and Structure Determination of} 2. Crystals of $\mathbf{2}$ suitable for an X-ray diffraction study were obtained by slow diffusion of ethanol into $\mathrm{CS}_{2}$ solution. Data collection was carried out on a Bruker SMART diffractometer/CCD area detector at $293 \mathrm{~K}$. Preliminary orientation matrix and cell constants were determined from three series of $\omega$ scans at different start angles. The hemisphere of reflection data were collected at scan interval of $0.5^{\circ} \mathrm{\omega}$

Table 1. Crystal and structure determination data for $20.5 \mathrm{CS}$.

\begin{tabular}{|c|c|}
\hline & $\operatorname{Ir}(\mathrm{H})(\mathrm{CO})\left(\mathrm{PEt}_{3}\right)_{2}\left(\eta \vec{f}-\mathrm{C}_{60}\right)$ \\
\hline formula & $\mathrm{C}_{73} \mathrm{H}_{31} \mathrm{P}_{2} \mathrm{OIr} \cdot 0.5 \mathrm{CS}_{2}$ \\
\hline fw & 1216.18 \\
\hline cryst system & monoclinic \\
\hline space group & $P 2 / \mathrm{n}$ \\
\hline$a, \AA$ & $14.9465(4)$ \\
\hline$b, \AA$ & $16.5758(4)$ \\
\hline$c, \AA$ & $18.8214(5)$ \\
\hline$\alpha$, deg. & 90 \\
\hline$\beta$, deg. & $108.448(1)$ \\
\hline$\gamma$, deg. & 90 \\
\hline$V, \AA^{3}$ & $4423.4(2)$ \\
\hline Z & 4 \\
\hline$D_{c u l d d}, \mathrm{~g} \mathrm{~cm}^{-3}$ & 1.826 \\
\hline temp, $\mathrm{K}$ & $293(2)$ \\
\hline$\hat{\lambda}(\mathrm{MoK} \alpha), \AA$ & 0.71073 \\
\hline$\mu, \mathrm{mm}^{-1}$ & 3.197 \\
\hline$\theta$ range for collection & $1.53^{\circ}<\theta<28.30^{\circ}$ \\
\hline no. of tflns measd & 40047 \\
\hline no. of unique rflns & 10898 \\
\hline$R_{\mathrm{int}}$ & 0.0312 \\
\hline goodness of fit & 1.055 \\
\hline$R_{1}$ & 0.0407 \\
\hline $\mathrm{wR} 2^{b}$ & 0.1102 \\
\hline
\end{tabular}

within a exposure time of 20 seconds per frame. The data were corrected for Lorentz and polarization effects, but no correction for crystal decay was applied. Absorption corrections were performed using SADABS..$^{12}$ Relevant crystallographic data are summarized in Table 1. Structure was solved by direct ${ }^{13}$ and difference Fourier methods and was refined by full-matrix least-squares methods based on $F^{2}$ (SHELX 97). ${ }^{14}$ All non-hydrogen atoms were refined with anisotropic thermal coefficients. The metal hydride was located from the difference electron density map and refined with an isotropic thermal parameter.

Crystallographic data for the structure reported here have been deposited with the Cambridge Crystallographic Data Centre (Deposition No. CCDC-656226). The data can be obtained free of charge via www.ccde.cam.ac.uk/conts/ retrieving.html (or from the CCDC, 12 Union Road, Cambridge CB2 1EZ, UK; fax: +44 1223 336033; e-mail: deposit@cadc.cam.ac.uk).

\section{Results and Discussion}

Synthesis and Characterization of 2. In our previous work, reaction of $\operatorname{Ir}_{4}(\mathrm{CO})_{8}\left(\mathrm{PMe}_{3}\right)_{4}$ (4) with excess (4 equiv) $\mathrm{C}_{60}$ in refluxing 1,2-dichlorobenzene, followed by treatment with $\mathrm{CNCH}_{2} \mathrm{Ph}$ at $70^{\circ} \mathrm{C}$, affords a square-planar tetrairidium complex with two $\mathrm{C}_{60}$ ligands and a face-capping methylidyne ligand, $\mathrm{Ir}_{4}(\mathrm{CO})_{3}\left(\mu_{4}-\mathrm{CH}\right)\left(\mathrm{PMe}_{3}\right)_{2}\left(\mu-\mathrm{PMe}_{2}\right)\left(\mathrm{CNCH}_{2} \mathrm{Ph}\right)-$ $\left(\mu-\eta^{2}: \eta^{2}-\mathrm{C}_{60}\right)\left(\mu 4-\eta^{1}: \eta^{1}: \eta^{2}: \eta^{2}-\mathrm{C}_{60}\right)(\mathbf{5})$ as the major product as shown in the bottom of Scheme $1 .{ }^{15}$ In order to prepare a $\mu_{4}-\mathrm{CCH}_{3}$ analogue of 5 , a similar reaction of tetrakistriethylphosphine-substituted compound $\mathrm{Ir}_{4}(\mathrm{CO})_{8}\left(\mathrm{PEt}_{3}\right)_{4}$ (1) with $\mathrm{C}_{60}$ was carried out, unexpectedly, to give a hydrido monoiridium fullerene complex $\operatorname{Ir}(\mathrm{H})(\mathrm{CO})\left(\mathrm{PEt}_{3}\right)_{2}\left(\eta^{2}-\mathrm{C}_{(0)}\right)(2)$ by fragmentation of the tetrairidium cluster framework (the top of Scheme 1).

Formulation of $\mathbf{2}$ is supported by elemental analysis and by the molecular ion $\left(\mathrm{M}^{+}\right)$multiplet in the positive ion $\mathrm{FAB}$ mass spectrum (MS). The $\mathrm{M}^{+}$multiplet in the MS of 2 matches perfectly the calculated pattern: the highest peaks in the $\mathrm{M}^{+}$multiplet ( $\mathrm{m} / \mathrm{z}$, found, calcd) are 1178,1178 . Compound 2 is soluble in common solvents such as THF, dichloromethane, chloroform, and carbon disulfide to form a green solution. This new compound decomposes slowly in solution at room temperature and must be kept in the refrigerator.

The IR spectrum of 2 shows an Ir-H stretching band at $2091 \mathrm{~cm}^{-1}$, which compares with those at $2082(\mathrm{Rh}-\mathrm{H})$ and $2102(\mathrm{Ir}-\mathrm{H}) \mathrm{cm}^{-1}$ in analogous complexes such as $\mathrm{Rh}(\mathrm{H})(\mathrm{CO})\left(\mathrm{PPh}_{3}\right)_{2}\left(\eta^{2}-\mathrm{C}_{60}\right)^{3 \mathrm{a}}$ and $\operatorname{Ir}(\mathrm{H})(\mathrm{CO})\left(\mathrm{PPh}_{3}\right)_{2}\left(\eta^{2}-\mathrm{C}_{60}\right),{ }^{9}$ respectively.

The ${ }^{1} \mathrm{H}$ NMR spectrum of $\mathbf{2}$ exhibit a hydride resonance at $-9.70 \mathrm{ppm}$ as a triplet $\left({ }^{2} J_{\mathrm{PH}}=18.8 \mathrm{~Hz}\right)$, which is typical for a hydride cis to two equivalent phosphorus atoms. The hydride resonances of $\mathrm{Rh}(\mathrm{H})(\mathrm{CO})\left(\mathrm{PPh}_{3}\right)_{2}\left(\eta^{2}-\mathrm{C}_{60}\right)$ and $\operatorname{Ir}(\mathrm{H})(\mathrm{CO})\left(\mathrm{PPh}_{3}\right)_{2}\left(\eta^{2}-\mathrm{C}_{60}\right)$ appeared at $-9.33 \mathrm{ppm}$ with ${ }^{2} J_{\mathrm{PH}}$ $=8.4 \mathrm{~Hz}$ and $-9.02 \mathrm{ppm}$ with ${ }^{2} J_{\mathrm{PH}}=17.3 \mathrm{~Hz}$, respectively. ${ }^{3.9}$ The ethyl proton resonances appear at $2.23(\mathrm{~m}, 12 \mathrm{H})$ for the 


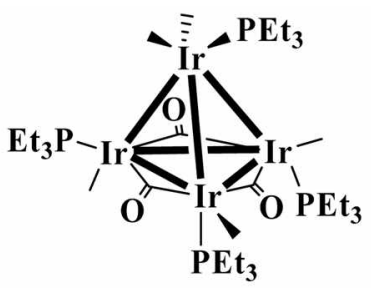

1

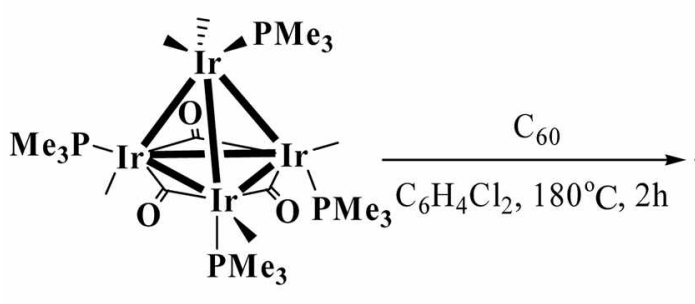

4

.
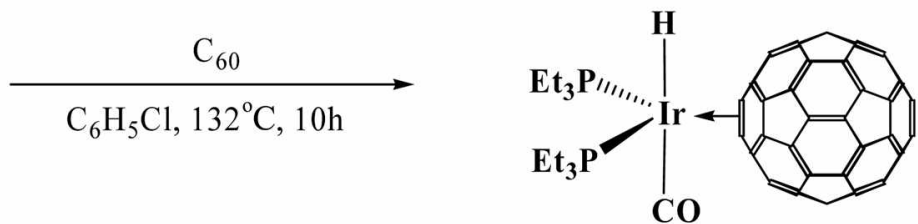

2

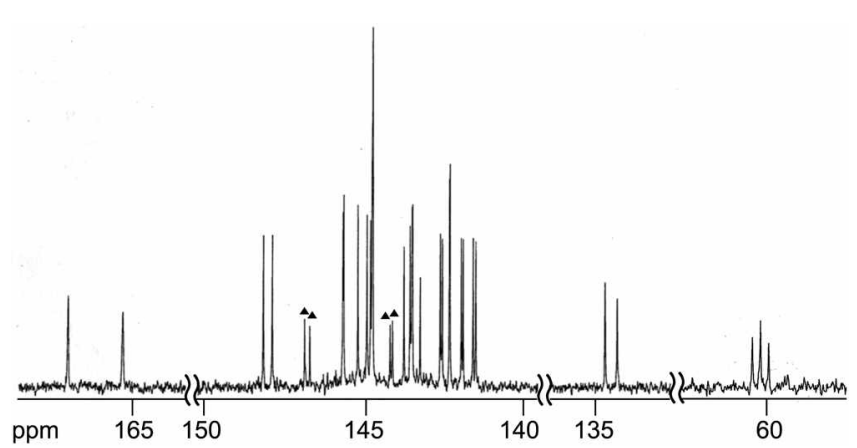

Figure 1. ${ }^{13} \mathrm{C}$ NMR spectrum $\left(100 \mathrm{MHz}, \mathrm{CS}_{2} / \mathrm{THF}_{-} \mathrm{d}_{4}, 298 \mathrm{~K}, \mathrm{C}_{60}\right.$ region) of 2.

methylene moieties and $1.34\left(\mathrm{dt}, 18 \mathrm{H}, J_{\mathrm{III}}=7.8 \mathrm{~Hz},{ }^{3} J_{\mathrm{PII}}=\right.$ $15.9 \mathrm{~Hz}$, for the methyl groups. The ${ }^{31} \mathrm{P}\left\{{ }^{1} \mathrm{H}\right\}$ NMR spectrum reveals a singlet at $-6.9 \mathrm{ppm}$ which is shifted to the higher field compared to that at $8.3 \mathrm{ppm}$ of $\operatorname{Ir}(\mathrm{H})(\mathrm{CO})$ $\left(\mathrm{PPh}_{3}\right)_{2}\left(\eta^{2}-\mathrm{C}_{60}\right)^{9}$

The ${ }^{13} \mathrm{C}$ NMR spectrum of 2 reveals a broad signal at 179.1 ppm for the carbonyl carbon of the one carbonyl ligand. The $C_{s}$ symmetric nature of 2 in solution shows the required number of ${ }^{13} \mathrm{C} N \mathrm{NR}$ resonances due to the $\mathrm{C}_{60}$

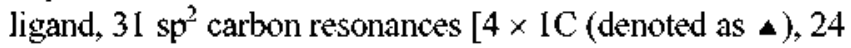
$\times 2 \mathrm{C}, 1 \times 6 \mathrm{C}$ (accidental coincidence of three resonances)] in the region of $\delta 170-130$ and one $\mathrm{sp}^{3}$ carbon resonance due to the two $\mathrm{sp}^{3}$ carbons bonded to the metal center exhibits a triplet at $\delta 60.3$ (Figure 1). The chemical shifts of the $\mathrm{C}_{60} \mathrm{sp}^{2}$ and $\mathrm{sp}^{3}$ carbon atoms for exohedral metallofullerenes are typically in the regions $\delta 175-135$ and $85-50$, respectively. In particular, the $\mathrm{sp}^{2}$ carbon atoms adjacent to the $\mathrm{sp}^{3}$ ones (referred to as $\mathrm{C} 2$ atoms) generally resonate at uniquely low fields above ca. $155 \mathrm{ppm}$, whereas those adjacent to the $\mathrm{C} 2$ atoms (referred to as $\mathrm{C} 3$ atoms) typically appear in the high field region below ca. $140 \mathrm{ppm}^{2 \mathrm{~b}}$ Therefore, the two low field resonances at $\delta 167.1(2 \mathrm{C})$ and $165.4(2 \mathrm{C})$ of 2 can be assigned to $\mathrm{C} 2$ type carbons and two high field resonances at $\delta 134.7(2 \mathrm{C})$ and $134.3(2 \mathrm{C})$ can be assigned to the $\mathrm{C} 3$ type

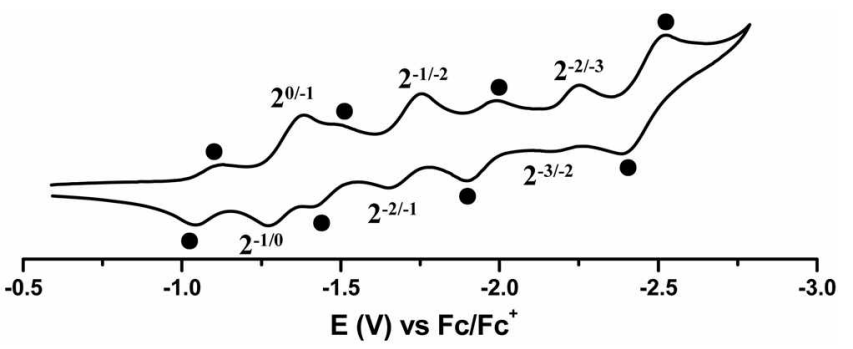

Figure 2. Cyclic voltaminograin of 2 in dry deoxygenated chlorobenzenc $\left.\left(0.1 \mathrm{M}\left[(n-\mathrm{Bu})_{4} \mathrm{~N}\right] \mathrm{ClO}\right)_{4}\right)$. Scan rate $=50 \mathrm{mV} / \mathrm{s}$.

carbons of $\mathrm{C}_{60}$ ligand. The $C_{5}$ symmetric complex, Rh(NO)$\left(\mathrm{PPh}_{3}\right)\left(\eta^{2}-\mathrm{C}_{60}\right)$, has been previously reported to show $31 \mathrm{sp}^{2}$ and one $\mathrm{sp}^{3}$ resonance including the two low field $\mathrm{C} 2$ resonances around $160 \mathrm{ppm}$ and the two high field $\mathrm{C} 3$ resonances around $136 \mathrm{ppm}$ by Green and coworkers. ${ }^{2 \mathrm{~h}}$

Electrochemical Study of 2 . The electrochemical property of $\mathbf{2}$ has been examined by cyclic voltammetry in chlorobenzene (CB) solution with tetrabutylammonjum perchlorate as the supporting electrolyte. The cyclic voltammogram (CV) of 2 is shown in Figure 2 and reveals seven reversible redox couples in the $\mathrm{CB}$ potential window. Their half-wave potentials are provided, together with free $\mathrm{C}_{60}{ }^{16}$ and other known Group 9 and 10 transition metal $\eta^{2}-C_{60}$ complexes with phosphine ligands for comparison in Table 2.

The three redox waves at $-1.33,-1.70$, and $-2.16 \mathrm{~V}$ are due to three successive one-electron reductions localized at $\mathrm{C}_{60}$ of 2 corresponding to formation of $2^{-}, 2^{2-}$, and $2^{3-}$. The other four waves (denoted as $\bullet$ ) at $-1.08,-1.44,-1.94$, and $-2.45 \mathrm{~V}$ are assigned to redox reactions of free $\mathrm{C}_{60}$ formed by decomposition of 2 in the reduced states during cyclic voltammetry. It is well documented that most of the known $\eta^{2}-\mathrm{C}_{60}$ transition metal complexes are unstable in the reduced states to release metal fragment and formations of the anions $\mathrm{C}_{60}, \mathrm{C}_{60}{ }^{2-}$, and $\mathrm{C}_{60}{ }^{3-}$, respectively, although $\mathrm{Rh}(\mathrm{H})\left(\mathrm{CH}_{3} \mathrm{C}-\right.$ $\left.\left(\mathrm{CH}_{2} \mathrm{PPh}_{2}\right)_{3}\right)\left(\eta^{2}-\mathrm{C}_{60}\right)$ complexes display exceptional stability 
Table 2. Half-wave potentials ( $\mathrm{E}_{1 / 2}$ \&s $\mathrm{E}_{\mathrm{Fe}}^{\circ} \mathrm{Fi}^{-}$) of $\mathrm{C}_{60}$, free $\mathrm{C}_{60}$ with 2 , and 2

\begin{tabular}{|c|c|c|c|c|c|c|}
\hline compound & $\mathrm{E}_{1: 2^{0}}{ }^{0-1}$ & $\mathrm{E}_{1 / 2}{ }^{-1 ;-2}$ & $\mathrm{E}_{1 / 2} 2^{-2 i-3}$ & $\mathrm{E}_{1 / 2}{ }^{-3 /-4}$ & solvent & ref \\
\hline $\mathrm{C}_{61}$ & -1.06 & -1.43 & -1.91 & -2.38 & $\mathrm{CB}$ & 16 \\
\hline a mixture of $\mathrm{C}_{61}$ with 2 (denoted as $\bullet$ ) & -1.08 & -1.44 & -1.94 & -2.45 & $\mathrm{CB}$ & This work \\
\hline $\left.\left.\mathrm{Ir}(\mathrm{H})(\mathrm{CO})(\mathrm{PEt})_{3}\right)\left(\eta^{*}-\mathrm{C}_{6}\right)\right)(2)$ & -1.33 & -1.70 & -2.16 & & $\mathrm{CB}$ & This work \\
\hline $\mathrm{Rh}\left(\mathrm{H}_{x}\left(\mathrm{CH}_{3} \mathrm{C}\left(\mathrm{CH}_{2} \mathrm{PPh}_{2}\right)_{3}\right)\left(\eta-\mathrm{C}_{60}\right)\right.$ & -1.37 & -1.75 & & & DCB & 17 \\
\hline $\mathrm{Co}\left(\mathrm{NO} y\left(\mathrm{PPh}_{3}\right)\left(\eta^{2}-\mathrm{C}_{60}\right)\right.$ & -1.17 & -1.72 & -2.25 & & THF & $6 c$ \\
\hline $\mathrm{Pt}\left(\mathrm{PEt}_{3}\right)_{2}\left(\eta T-\mathrm{C}_{60}\right)$ & -1.20 & -1.73 & -2.27 & & THF & $18 \mathrm{a}$ \\
\hline $\left.\mathrm{Pd}(\mathrm{PEt})_{2}\right)\left(\eta^{2}-\mathrm{C}_{60}\right)$ & -1.18 & -1.69 & -2.23 & & THF & $18 \mathrm{a}$ \\
\hline $\mathrm{Ni}\left(\mathrm{PEt}_{3}\right)_{2}\left(\eta^{2}-\mathrm{C}_{60}\right)$ & -1.20 & -1.74 & -2.32 & & THF & $18 \mathrm{a}$ \\
\hline
\end{tabular}

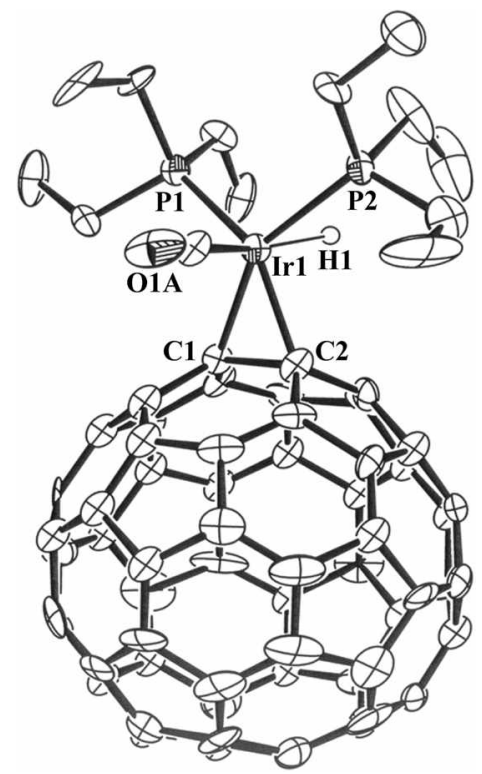

Figure 3. Molecular geometry and atomic-labeling scheme for 2 .

both thermally and electrochemically. ${ }^{17}$ The three redox waves of $\mathbf{2}$ are shifted to more negative potentials than those of free $\mathrm{C}_{60}$ by 270,270 , and $250 \mathrm{mV}$, respectively, because of both the metal-to- $\mathrm{C}_{60} \pi$-back-donation and the electron donating nature of the phosphine ligands. Comparable cathodic shifts have been observed previously in other phosphine-substituted complexes such as $\left(\mathrm{Et}_{3} \mathrm{P}\right)_{2} \mathrm{M}\left(\eta^{2}-\mathrm{C}_{60}\right)$ $(\mathrm{M}=\mathrm{Ni}, \mathrm{Pd}, \mathrm{Pt}),{ }^{18}$ and $\mathrm{Rh}(\mathrm{H})\left(\mathrm{CH}_{3} \mathrm{C}\left(\mathrm{CH}_{2} \mathrm{PPh}_{2}\right)_{3}\right)\left(\eta^{2}-\mathrm{C}_{60}\right)^{17}$ as listed in Table 2. The electron donating addenda to $\mathrm{C}_{\text {se }}$ are known to raise the $\mathrm{C}_{60}$-localized LUMO energy and thus decrease the electron affinity of $\mathrm{C}_{60}$, resulting in the observed cathodic shift. Complex 2 , however, is relatively electrochemically stable compared to other known $\eta^{2}-\mathrm{C}_{60}$ complexes, which generally undergo fast decomposition in the reduced states.

Molecular Structure of 2. The overall geometry and atomic labeling scheme of $\mathbf{2}$ are illustrated in Figure 3, and selected interatomic distances and angles are listed in Table 3 . The iridium atom of $\mathbf{2}$ is coordinated by two axial ligands of a hydrogen atom and a carbonyl group, and three equatorial ligands of two phosphorus atoms and an $\eta^{2}-\mathrm{C}_{60}$ moiety. The $\mathrm{C}_{60}$ ligand is bound to the iridium atom in an $\eta^{2}$ fashion at the 6-6 ring junction, as generally found in other
Table 3. Sclected interatomic distances $(\hat{\Lambda})$, angles (deg), and Esd's for 2

\begin{tabular}{|c|c|c|c|}
\hline \multicolumn{4}{|c|}{ Bond Lengths $(\AA)$} \\
\hline $\mathrm{Ir}-\mathrm{P} 1$ & $2.281(6)$ & $\mathrm{It}-\mathrm{P} 2$ & $2.394(6)$ \\
\hline $\mathrm{Ir}-\mathrm{Cl}$ & $2.17(2)$ & $\mathrm{Ir}-\mathrm{C} 2$ & $2.15(2)$ \\
\hline $\mathrm{Ir}-\mathrm{H}$ & $1.5(2)$ & $\mathrm{C} 1-\mathrm{C} 2$ & $1.46(3)$ \\
\hline \multicolumn{4}{|c|}{ Angles (deg) } \\
\hline $\mathrm{Ir}-\mathrm{C} 1-\mathrm{C} 2$ & $70(1)$ & $\mathrm{P} 1-\mathrm{Jr}-\mathrm{P} 2$ & $87.8(2)$ \\
\hline $\mathrm{Ir}-\mathrm{C} 2-\mathrm{C} 1$ & $71(1)$ & $\mathrm{C} 1-\mathrm{II}_{\mathrm{L}}-\mathrm{H}$ & $98(7)$ \\
\hline $\mathrm{C} 1-\mathrm{I}-\mathrm{P} 1$ & $117.0(6)$ & C2-JI-H & $94(7)$ \\
\hline $\mathrm{C} 1-\mathrm{I} \mathrm{l}-\mathrm{P} 2$ & $104.0(6)$ & Pl-Jr-H & $81(7)$ \\
\hline $\mathrm{C} 2-\mathrm{I} \mathrm{l}-\mathrm{P} 1$ & $155.7(5)$ & P2-Jr-H & $157(7)$ \\
\hline $\mathrm{C} 2-\mathrm{II}_{\mathrm{I}}-\mathrm{P} 2$ & $103.1(5)$ & & \\
\hline
\end{tabular}

$\eta^{2}-\mathrm{C}_{60}$ metallofullerens. The general structural features of 2 are similar to those of the structurally characterized $\operatorname{Ir}(\mathrm{Cl})(\mathrm{CO})\left(\mathrm{PPh}_{3}\right)_{2}\left(\eta^{2}-\mathrm{C}_{60}\right)$ and $\mathrm{Rh}(\mathrm{H})(\mathrm{CO})\left(\mathrm{PPh}_{3}\right)_{2}\left(\eta^{2}-\mathrm{C}_{60}\right)$ complexes. The Ir-C(carbonyl) bond length $(1.932(6) \AA$ ) of 2 compares with the Rh-C(carbonyl) bond length (1.934(9) $\AA$ ) of $\mathrm{Rh}(\mathrm{H})(\mathrm{CO})\left(\mathrm{PPh}_{3}\right)_{2}\left(\eta{ }^{3}-\mathrm{C}_{60}\right){ }^{3{ }^{3 a}}$ The Ir-H bond length $(1.57(6) \AA)$ is comparable to the $\mathrm{Rh}-\mathrm{H}$ bond length $(1.5(2)$ $\AA$ ) observed in $\mathrm{Rh}(\mathrm{H})\left(\mathrm{CH}_{3} \mathrm{C}\left(\mathrm{CH}_{2} \mathrm{PPh}_{2}\right)_{3}\right)\left(r^{2}-\mathrm{C}_{(0)}\right)^{17}$. The hydride ligand is directly located from the crystallographic study at the opposite axial position of the carbonyl ligand. The distance of the $\mathrm{Cl}-\mathrm{C} 2$ bond coordinated to the iridium atom is $1.507(8) \AA$ (cf. $1.53(3) \AA$ in $\operatorname{Ir}(\mathrm{Cl})(\mathrm{CO})\left(\mathrm{PPh}_{3}\right)\left(\eta^{2}-\right.$ $\left.\mathrm{C}_{60}\right),{ }^{10} 1.46(3) \AA$ in $\mathrm{Rh}(\mathrm{H})\left(\mathrm{CH}_{3} \mathrm{C}\left(\mathrm{CH}_{2} \mathrm{PPh}_{2}\right)_{3}\right)\left(\eta^{2}-\mathrm{C}_{60}\right),{ }^{17}$ and $1.48(1) \AA$ in $\left.\mathrm{Rh}(\mathrm{H})(\mathrm{CO})\left(\mathrm{PPh}_{3}\right)_{2}\left(\eta-\mathrm{C}_{60}\right)^{32}\right)$. This bond is elongated due to the metal-to- $\mathrm{C}_{60} \pi$-back-donation relative to $1.38 \AA$ for an unperturbed $(6,6)$-bond. The $\mathrm{Ir}-\mathrm{C}\left(\mathrm{C}_{60}\right)$ bond distances are $\mathrm{Ir}-\mathrm{Cl}=2.146(5) \AA$ and $\mathrm{Ir}-\mathrm{C} 2=2.164(5) \AA$, which are comparable to those of average $2.19(2) \AA$ for $\operatorname{Ir}(\mathrm{Cl})(\mathrm{CO})\left(\mathrm{PPh}_{3}\right)_{2}\left(\eta^{2}-\mathrm{C}_{60}\right),{ }^{10}$ and $2.16(2) \AA$ for $\mathrm{Rh}(\mathrm{H})$ $\left.\left(\mathrm{CH}_{3} \mathrm{C}_{\left(\mathrm{CH}_{2}\right.} \mathrm{PPh}_{2}\right)_{3}\right)\left(\eta^{2}-\mathrm{C}_{(0)}\right){ }^{17}$

All other features of the molecular geometry are within the expected ranges. The average $\mathrm{C}-\mathrm{C}$ bond length of the $\mathrm{C}_{60}$ moiety at the junction of the 5,6 ring is $1.536(8) \AA$ and that at the junction of the 6,6 ring is $1.37(1) \AA$.

\section{Conclusion}

Hydrido monoiridium fullerene complex $\operatorname{Ir}(\mathrm{H})(\mathrm{CO})$ $\left(\mathrm{PEt}_{3}\right)_{2}\left(\eta_{2}-\mathrm{C}_{60}\right)(2)$ has been prepared by the reaction of tetrakistriethylphosphine-substituted compound $\mathrm{Ir}_{+}(\mathrm{CO})_{8-}$ 
$\left(\mathrm{PEt}_{3}\right)_{4}(1)$ with $\mathrm{C}_{60}$ in refluxing chlorobenzene. Compound 2 has been fully characterized by various spectroscopic (IR, $\mathrm{MS},{ }^{1} \mathrm{H}$ and ${ }^{13} \mathrm{C}-\mathrm{NMR}$ ) methods, cyclic voltammetry, and $\mathrm{X}$ ray diffraction study. Compound 2 is, to our knowledge, the first example of structurally characterized hydrido iridium $\eta^{2}-\mathrm{C}_{60}$ complex.

Acknowledgment. This work was supported by the Korea Research Foundation Grant funded by the Korean Govemment (MOEHRD) (KRF-2005-201-C00021) and by the Nano R\&D program (Grant No. 2005-02618) of the Korea Science and Engineering Foundation (KOSEF) funded by Korean Ministry of Science \& Technology (MOST). This work was also supported in part by the SRC program (Grant No. R11-2005-008-03001-0) of the KOSEF through the Center for Intelligent Nano-Bio Materials at Ewha Womans University.

\section{References}

1. Fagan, P. J.; Calabrese, J. C.; Malone, B. Science 1991, 252, 1160 .

2. (a) Balch, A. L.; Olmstead, M. M. Chem. Rev 1998, 98, 2123. (b) Sephens, A. H. H.; Green, M. L. H. Act. Inorg. Chem. 1997, 44, 1 . (c) Bowser, J. R, AAv, Organomet, Chem. 1994, 36, 57.

3. (a) Balch, A. L.; Lee, J. W; Noll, B. C.; Olmstead, M. M. Inorg. Chem. 1993, 32, 3577. (b) Ishii, Y,; Hashi, H.; Hamada, Y,; Hidai, M. Chem. Lett 1994. 801 .

4. (a) Balch, A. L.; Catalano, V. J.; Lee, J. W. Inorg. Chen. 1991, 30 , 3980. (b) Koefod. R. S.; Hudgens, M. F.; Shapley, J. R. J. An. Chem. Soc. 1991, 113, 8957. (c) Fagan, P. J.; Calabrese, J. C.; Malone, B. Acc. Chem. Res. 1992, 25, 134.

5. (a) Douthwaite, R. E.; Green, M. L. H.; Stephens, A. H. H.; Turner, J. F. C. J. Chen. Soc. Chem. Commun. 1993, 1522. (b)
Green, M. L. H.; Stephens, A. H. H. J. Chem. Soc. Chem Conmmun 1997, 793. (c) Hsu, H.-F.; Du, Y; Albrecht-Schmitt, T. E.; Wilson, S. R.; Shapley, J. R. Organontetallics 1998, 17, 1756.

6. (a) Rasinkangas, M.; Pakkanen, T. T.; Pakkanen, T. A.; Ahlgrén, M.; Rouvinen, J. J. Am. Chem. Soc. 1993, 115, 4901. (b) Mavunkal, I. J.; Chi, Y.; Peng, S.-M.; Lee, G.-H. Organometallics 1995, 14, 4454. (c) Chernega, A. N.; Green, M. L. H.; Haggith, J.; Stephens, A. H. H. J. Chem. Soc. Dalton Trans. 1998, 755.

7. (a) Lee, K.; Song, H.; Park, J. T. Acc. Chem. Res. 2003, 36, 78. (b) Hsu, H.-F.; Shapley, J. R. J. Am. Chem. Soc. 1996, 118, 9192. (c) Lee, K.; Hsu, H.-F.; Shapley, J. R. Organometallics 1997, 16, 3876. (d) Park, J. T.; Song, H.; Cho, J.-J.; Chung, M.-K.; Lee, J.H.; Suh, J.-H. Organometallics 1998, 17, 227. (e) Song, H.; Lee, K.; Park, J. T.; Choi, M.-G Organometallics 1998, $17,4477$.

8. (a) Wilkinson, G.; Schunn, R. A.; Peet, W. G. Inorg. Synthesis 1972, 13, 126. (b) Vaska, L. Inorg. Nicl. Chem. Letters 1965, 1 , 89. (c) Schunn, R. A. Inorg. Chem, 1970, 9, 2567.

9. Schreiner, S.; Gallaber, T. N.; Parsons, H. K. Inorg. Chem. 1994, 33,3021 .

10. Balch, A. L.; Catalano, V. J.; Lee, J. W. Inorg. Chem. 1991, 30 , 3980.

11. Drakesmith, A. J.; Whyman, R. J. Chem. Soc., Dalton Trans. $1973,362$.

12. Sheldrick, G. M. SADABS-A Program for Area Detector Absorption Corrections; University of Göttingen: Genmany, 1994.

13. Sheldrick, G. M. Acta Cnystallogr. $A$ 1990, 46, 467.

14. Sheldrick, G. M. SHELX97, Program for Crystal Structure Refinement; University of Göttingen: Germany, 1997.

15. Lee, G.; Cho, Y.-J.; Park, B. K.; Lee, K.; Park, J. T. J. Am. Chem. Soc, $2003,125,13920$.

16. Song, H.; Lee, Y.; Choi, Z.-H.; Lee, K.; Park, J. T.; Kwak, J.; Choi, M.-G. Organtonetallics 1998, 17, 4477.

17. Song, H.; Lee, K.; Park, J. T.; Suh, I.-H. J. Organonef. Chent. $1999,584,361$.

18. (a) Lerke, S. A.; Parkinson, B. A.; Evans, D. H.; Fagan, P. J. J. Am. Chem. Soc. 1992, 114, 7807. (b) Koefod, R. S.; Xu, C.; Lu, W; Shapley, J. R.; Hill, M. G; Mann, K. R. J. Phys. Chem. 1992, $96,2928$. 